\title{
Soil Zinc Fertilization of 'Wichita' Pecan Trees Growing Under Alkaline Soil Conditions
}

\author{
Humberto Núñez-Moreno \\ Instituto Nacional de Investigaciones Forestales y Agropecuarias, Carr. \\ Bahia de Kino Km 12.6, Hermosillo, Sonora, México, 83220
}

James L. Walworth ${ }^{\mathbf{1}}$ and Andrew P. Pond

Department of Soil, Water and Environmental Science, University of Arizona, 429 Shantz Building \#38, 1177 E. Fourth Street, Tucson, AZ 85721

Michael W. Kilby

Department of Plant Science, University of Arizona, 303 Forbes Building \#36, Tucson, AZ 85721

Additional index words. Carya illinoinensis, Zn EDTA, nut quality, yield, mineral composition

\begin{abstract}
The effect of soil banding zinc sulfate and zinc (Zn)-EDTA was evaluated over a period of 4 years on established 'Wichita' pecans [Carya illinoinensis (Wangenh.) $\mathrm{K}$. Koch] growing in alkaline, calcareous soil. Treatments evaluated were $\mathrm{ZnSO}_{4}$ applied at $74 \mathrm{~kg} \mathrm{Zn} / \mathrm{ha}$ and $\mathrm{Zn}$-EDTA at $19 \mathrm{~kg} \mathrm{Zn/ha}$. These materials were applied just once on 23 Mar. 2005. Fertilizers were injected in two bands placed $1.2 \mathrm{~m}$ from either side of the trunk of the tree and $18 \mathrm{~cm}$ deep. Treatments were replicated four times in a randomized complete block design. Data collected included foliar $\mathrm{Zn}$ concentrations throughout the season, midseason foliar nutrient concentrations, leaflet growth, nut yield, and nut quality. Significant differences in foliar $\mathrm{Zn}$ levels were found 1 month after application of Zn-EDTA. Differences also were noted during the next 3 years on $\approx 25 \%$ of the sampling dates. Yields of in-shell pecans averaged $2800 \mathrm{~kg} \cdot \mathrm{ha}^{-1}$ during the 3 years of harvest but were unaffected by treatments. Nut quality also was unaffected. Nut kernel percentage was very high, ranging from $61.2 \%$ to $63.6 \%$ during the study. Growth, measured as leaflet area and trunk cross-sectional area, was unaffected by $\mathrm{Zn}$ application. Chlorophyll index ranged from 47.5 to 48.0 in 2007 and from 44.7 to 45.4 in 2008 and was unaffected by applied treatments. Zn-EDTA increased Zn uptake slightly by 'Wichita' pecan trees in alkaline, calcareous conditions during 3 years after one soil band injection. Ongoing research on potted pecan trees (with the same soil used in the present study) suggests that $\mathrm{Zn}$-EDTA can very effectively increase $\mathrm{Zn}$ uptake if placed in close proximity to the tree roots. Additional research is needed to refine application and placement methods in these types of soils to produce a more effective and consistent response.
\end{abstract}

Spraying zinc $(\mathrm{Zn})$ solutions onto the tree canopy is the standard method for supplying this nutrient to pecan trees [Carya illinoinensis (Wangenh.) K. Koch]. Zinc applied to soil reacts with hydroxyls and carbonates in alkaline and calcareous soils forming compounds of low solubility, limiting its plant availability (Agbenin, 2003; Lindsay, 1979; Udo et al., 1970). Foliar Zn sprays can reliably increase leaf $\mathrm{Zn}$ levels over threshold levels of $\approx 50 \mu \mathrm{g} \cdot \mathrm{g}^{-1}$, but this method has several disadvantages. Foliar application is time-consuming, requires investment in expensive equipment, uses fuel, repeated traffic through the orchard causes soil compaction, and spray schedules interfere with management in the orchard (mainly with irrigation). Additionally, repeated appli-

Received for publication 13 May 2009. Accepted for publication 21 July 2009.

${ }^{1}$ To whom reprint requests should be addressed; e-mailwalworth@ag.arizona.edu. cations are required during the growing season as a result of low mobility of sprayed Zn within the tree (Grauke et al., 1982; Wadsworth, 1970). Because of these disadvantages, growers would benefit from an effective and efficient method of applying $\mathrm{Zn}$ fertilizers to the soil.

Soil application of $\mathrm{Zn}$ has been successful in the acidic soils of the southeast United States (Sparks, 1976; Wood, 2007) but is much less likely to be effective in alkaline and, particularly, calcareous soils.

Response of pecan to soil $\mathrm{Zn}$ application can take several years depending on application rate, form of fertilizer, and method of application. On an acid soil in Georgia, using zinc sulfate ( $35 \mathrm{~kg} \mathrm{Zn} / \mathrm{ha})$, zinc oxide (35 kg $\mathrm{Zn} / \mathrm{ha}$ ), and $\mathrm{Zn}$-EDTA (3.5 kg Zn/ha), recovery of a $\mathrm{Zn}$-deficient orchard was very slow, and it took 3 to 4 years to reach the optimum $\mathrm{Zn}$ levels in the leaf and eliminate deficiency symptoms (Worley et al., 1972). Zinc application rates from 0 to $4224 \mathrm{~g} \mathrm{Zn/tree} \mathrm{(as}$ either $\mathrm{ZnSO}_{4}$ or $\mathrm{ZnO}$ ) placed over drip irrigation lines were evaluated on 4-yearold 'Desirable' trees in an acid soil in Georgia. In the first year of evaluation, 4 months after application, trees that received rates higher than $528 \mathrm{~g} \mathrm{Zn}$ /tree had leaf $\mathrm{Zn}$ levels over $50 \mu \mathrm{g} \cdot \mathrm{g}^{-1}$. In the second year, only those with rates of at least $2112 \mathrm{~g} \mathrm{Zn} /$ tree had leaf $\mathrm{Zn}$ levels over $50 \mu \mathrm{g} \cdot \mathrm{g}^{-1}$, and in the fourth year after application, treatments with rates higher than $132 \mathrm{~g}$ per tree had greater than $50 \mu \mathrm{g} \cdot \mathrm{g}^{-1}$ of $\mathrm{Zn}$ in the leaves (Wood, 2007). In contrast, extremely high rates, as much as $126 \mathrm{~kg}$ of $\mathrm{ZnSO}_{4} /$ tree, were needed to provide adequate $\mathrm{Zn}$ to pecan trees in a calcareous soil in Texas (Storey et al., 1971).

In a study of several forms of $\mathrm{Zn}$ fertilizer, $\mathrm{ZnSO}_{4}, \mathrm{ZnO}$, and $\mathrm{Zn}$-EDTA were broadcast or placed in holes (six holes, each $2.5 \mathrm{~cm}$ in diameter $\times 30 \mathrm{~cm}$ depth) in a Georgia soil that had been limed to a $\mathrm{pH}$ of 7.4 (Worley et al., 1972). Broadcast applications of either $\mathrm{ZnO}$ (applied at $22 \mathrm{~g} \cdot \mathrm{cm}^{-1}$ of trunk circumference, applied annually over 5 years) or Zn-EDTA $\left(3.3 \mathrm{~g} \cdot \mathrm{cm}^{-1}\right)$ increased leaf $\mathrm{Zn}$ relative to the untreated control; $\mathrm{ZnSO}_{4}$ placed in holes did not. Response to broadcast Zn-EDTA was significant in Year 2, whereas $\mathrm{ZnO}$ effects were not apparent until Year 5. Zinc sulfate had no significant effect regardless of placement. Extractability of $\mathrm{Zn}^{2+}$ in soils treated with EDTA at rates of 0.1 and $0.2 \mathrm{mg} \cdot \mathrm{kg}^{-1}$ soil was increased as EDTA rate was increased (Karaca et al., 2000). DTPA-extractable $\mathrm{Zn}$ was 6.29 for the $0.1 \mathrm{mg} \cdot \mathrm{kg}^{-1}$ rate and $7.57 \mathrm{mg} \cdot \mathrm{kg}^{-1}$ for the $0.2 \mathrm{mg} \cdot \mathrm{kg}^{-1}$ rate versus $2.07 \mathrm{mg} \cdot \mathrm{kg}^{-1}$ in the control. In a field demonstration study in Texas, Zn-EDTA was applied through a drip irrigation system in 1974 at annual rates of $0.8,1.6$, and $2.5 \mathrm{~kg}$ $\mathrm{Zn} / \mathrm{ha}$ (Lindsey and Condra, unpublished data). Resulting leaf $\mathrm{Zn}$ levels were 39, 53, and $68 \mu \mathrm{g} \cdot \mathrm{g}^{-1}$, respectively. In 1975, the corresponding leaf $\mathrm{Zn}$ levels were 49, 54, and $70 \mu \mathrm{g} \cdot \mathrm{g}^{-1}$, respectively. These data suggest that drip irrigation-applied Zn-EDTA elevated leaf $\mathrm{Zn}$ levels; however, no unfertilized controls were included, and the data were not statistically analyzed.

Zinc fertilizer placement is also critical. $\mathrm{ZnO}$ and $\mathrm{ZnSO}_{4}$ were broadcast on a limed Georgia soil with a pH of 7.3 in the top $2.5 \mathrm{~cm}$ and 6.2 in the $2.5 \mathrm{~cm}$ below that. A single application of $160 \mathrm{~kg} \mathrm{Zn/ha}$ of either material increased tissue $\mathrm{Zn}$ above $50 \mu \mathrm{g} \cdot \mathrm{g}^{-1}$ in Year 2 when disked into the soil and in Year 4 when not incorporated (Wood and Payne, 1997). In another study, an application of $\mathrm{ZnSO}_{4}$ was banded ( 0 to $391 \mathrm{~kg} \cdot \mathrm{ha}^{-1}$ ) or broadcast ( 0 to $448 \mathrm{~kg} \cdot \mathrm{ha}^{-1}$ ) on a Georgia soil with $\mathrm{pH}$ ranging from 4.8 to 5.2 in a single application. Leaf $\mathrm{Zn}$ levels increased over the next 5 years. Applications of at least $112 \mathrm{~kg} \mathrm{ZnSO}_{4} /$ ha broadcast or $391 \mathrm{~kg} \mathrm{ZnSO}_{4} / \mathrm{ha}$ banded increased $\mathrm{Zn}$ levels to over $50 \mu \mathrm{g} \cdot \mathrm{g}^{-1}$. Greater broadcast application rates increased leaf $\mathrm{Zn}$ sooner; $448 \mathrm{~kg} \mathrm{ZnSO}_{4} /$ ha increased $\mathrm{Zn}$ above the $50 \mu \mathrm{g} \cdot \mathrm{g}^{-1}$ threshold in the second year, $224 \mathrm{~kg} \mathrm{ZnSO}_{4} /$ ha in Year 4 to 5 , and $112 \mathrm{~kg}$ $\mathrm{ZnSO}_{4} / \mathrm{ha}$ in Year 5. In banded treatments, $391 \mathrm{~kg} \mathrm{ZnSO}{ }_{4} /$ ha raised leaf $\mathrm{Zn}$ to $50 \mu \mathrm{g} \cdot \mathrm{g}^{-1}$ in Year 5 (Payne and Sparks, 1982b). 
There is a lack of studies of $\mathrm{Zn}$ applied to irrigated calcareous soils. We evaluated $\mathrm{Zn}$ uptake, tree growth, and nut yield after a one-time band application of $\mathrm{ZnSO}_{4}$ and $\mathrm{Zn}$ EDTA in a calcareous soil over a period of 4 years. The objective was to determine if these fertilizers can effectively enhance $\mathrm{Zn}$ uptake in young 'Wichita' pecan trees in an irrigated, alkaline desert soil.

\section{Materials and Methods}

A field study was conducted on a commercial pecan orchard in southeast Arizona (lat. $31^{\circ} 55^{\prime} 01.25^{\prime \prime} \mathrm{N}$, long. $110^{\circ} 57^{\prime} 27.56^{\prime \prime}$, elev. $844 \mathrm{~m}$ ) on 'Wichita' trees (7 years old) from May 2005 to Nov. 2008. The trees are growing in an alkaline and calcareous Pima clay loam soil with a soil $\mathrm{pH}$ of 7.6 (fine clayed, mixed, thermic, Typic Hapliargid). The soil is thermic and semiarid with mean annual soil temperprecipitation between 25 to $40 \mathrm{~cm}$ (Hendricks, 1985). Table 1 presents general soil characteristics of the orchard site at 0 to $30 \mathrm{~cm}$ depth. The soil is typical of many southwestern U.S. soils and therefore many regional pecan orchards. Trees are planted in a square design and the space between trees is $9.15 \mathrm{~m}$. The area between tree rows was mowed to keep the soil clean of weeds during the growing season. Trees were level basin flood-irrigated twice each month from April to October. A total of $1.50 \mathrm{~m}$ of water depth was applied annually. Beginning in 2007, the orchard was converted to organic production and pest control methods were changed accordingly. Before the block was converted to organic production, imidacloprid was soil-applied at a rate of $480 \mathrm{~g}$ a.i. per ha. After conversion to organic production, an insecticide-fungicide composed by potassium salts of fatty acids $(49 \% \mathrm{w} / \mathrm{w})$, propanol-glycol (specimen label for MPede $^{\circledR}$; Dow AgroSciences, Indianapolis, IN), was sprayed at least twice a year to the foliage at a rate of $1 \% \mathrm{v} / \mathrm{v}$ to reduce aphid populations. During the winter of 2006-2007, the trees in buffer rows between experimental plots were mechanically hedge-pruned. In the winter of 2007-2008, tree rows within plots were hedged. Trees were hedged $3 \mathrm{~m}$ from atures from 15 to $22{ }^{\circ} \mathrm{C}$ and a mean annual

each side of the trunk and $9 \mathrm{~m}$ high. Lateral hedge-pruning had an inclination of $5^{\circ}$ from the vertical toward the trunk with the top pruned at an angle of $160^{\circ}$.

Treatments evaluated were $\mathrm{ZnSO}_{4}$ applied at a rate of $74 \mathrm{~kg} \mathrm{Zn} / \mathrm{ha}$ and $\mathrm{Zn}$ EDTA at $19 \mathrm{~kg} \mathrm{Zn/ha}$ and an untreated control treatment that did not receive any $\mathrm{Zn}$ application. Zinc materials were applied once only, on 23 Mar. 2005. Zinc sulfate was applied in $840 \mathrm{~L} \mathrm{H}_{2} \mathrm{O} /$ ha with $0.0026 \mathrm{~mL}$ $\mathrm{H}_{2} \mathrm{SO}_{4} / \mathrm{L}$ to increase solubility. Zn-EDTA was applied in $380 \mathrm{~L} \mathrm{H}_{2} \mathrm{O} /$ ha. Fertilizer solutions were injected using a single shank in bands placed $1.2 \mathrm{~m}$ from the trunk of the trees and $18 \mathrm{~cm}$ depth. Each tree row received two fertilizer bands, one on each side of the row. Treatments were replicated four times in a randomized complete block design. Each plot consisted of one row of 15 trees $(n=12)$. Every experimental plot was separated by one buffer row. Leaf sampling and growth measurements were collected from the 11 central trees in each plot row. Analysis of variance was conducted with SAS (Version 9.1; SAS Institute, Cary, NC). Mean separation was conducted with Tukey's honestly significant difference.

Trunk circumferences were measured 20 $\mathrm{cm}$ above the ground for calculation of trunk cross-sectional area (TCSA) measurements. Trunk cross-sectional area was calculated from trunk circumferences in Feb. 2007 and Feb. 2008.

During 2005, 2006, 2007, and 2008, nut yield and quality were measured. Yield was calculated by mechanically harvesting the complete experimental plot. Cumulative nut yield was determined from the 4 years of harvest. Alternate bearing intensity was determined by the deviation of yield in successive years (Pearce and DobersekUrbanc, 1967) according to the formula:

$$
\begin{aligned}
I= & \frac{1}{n-1} *\left(\left|\frac{Y_{1}-Y_{2}}{Y_{1}+Y_{2}}\right|+\left|\frac{Y_{2}-Y_{3}}{Y_{2}+Y_{3}}\right|\right. \\
& \left.+\ldots+\left|\frac{Y_{n-1}-Y_{n}}{Y_{n-1}+Y_{n}}\right|\right)
\end{aligned}
$$

where $\mathrm{I}=$ alternate bearing intensity, $\mathrm{n}=$ total

\begin{tabular}{|c|c|c|c|}
\hline Soil test & Method & Units & $\overline{\text { Value }}$ \\
\hline$\overline{\mathrm{pH}}$ & Saturated paste & SU & 7.5 \\
\hline Electrical conductivity & Saturated paste & $\mathrm{dS} \cdot \mathrm{m}^{-1}$ & 0.44 \\
\hline Calcium & $\mathrm{NH}_{4} \mathrm{OAc}(\mathrm{pH} 8.5)$ & $\mathrm{mg} \cdot \mathrm{kg}^{-1}$ & 4000 \\
\hline Magnesium & $\mathrm{NH}_{4} \mathrm{OAc}(\mathrm{pH} 8.5)$ & $\mathrm{mg} \cdot \mathrm{kg}^{-1}$ & 310 \\
\hline Potassium & $\mathrm{NH}_{4} \mathrm{OAc}(\mathrm{pH} 8.5)$ & $\mathrm{mg} \cdot \mathrm{kg}^{-1}$ & 510 \\
\hline Zinc & DTPA & $\mathrm{mg} \cdot \mathrm{kg}^{-1}$ & 3.2 \\
\hline Iron & DTPA & $\mathrm{mg} \cdot \mathrm{kg}^{-1}$ & 5.1 \\
\hline Manganese & DTPA & $\mathrm{mg} \cdot \mathrm{kg}^{-1}$ & 9.4 \\
\hline Copper & DTPA & $\mathrm{mg} \cdot \mathrm{kg}^{-1}$ & 2.4 \\
\hline Nickel & DTPA & $\mathrm{mg} \cdot \mathrm{kg}^{-1}$ & 0.12 \\
\hline $\mathrm{NO}_{3}-\mathrm{N}$ & $\mathrm{Cd}$ reduction & $\mathrm{mg} \cdot \mathrm{kg}^{-1}$ & 8.8 \\
\hline $\mathrm{PO}_{4}-\mathrm{P}$ & Olsen & $\mathrm{mg} \cdot \mathrm{kg}^{-1}$ & 9.0 \\
\hline $\mathrm{SO}_{4}-\mathrm{S}$ & Hot water & $\mathrm{mg} \cdot \mathrm{kg}^{-1}$ & 22 \\
\hline Boron & Hot water & $\mathrm{mg} \cdot \mathrm{kg}^{-1}$ & 0.28 \\
\hline Free lime & Effervescence & & High \\
\hline Exchangeable sodium percent & Calculated & $\%$ & 1.8 \\
\hline Cation exchange capacity & Calculated & $\mathrm{cmol}_{\mathrm{c}} \cdot \mathrm{kg}^{-1}$ & 24.3 \\
\hline
\end{tabular}

Table 1. Orchard soil characteristics at the beginning of the study. of years, and $\mathrm{Y}=$ year. Values are absolute numbers.

A subsample of $\approx 5 \mathrm{~kg}$ of the harvested nuts was used to determine meat yield, percent of good nuts, and stick-tight nuts (fruit with shuck remaining stuck to the shell after harvest). Yield efficiency was determined by calculating yield of nuts per square centimeter of tree TCSA. Kernel percent was determined by cracking 10 nuts from each experimental plot and separately weighing the shell and kernel. Weight per nut was calculated by counting the number of nuts per kilogram.

Twenty middle pairs of exterior leaflets from the leaves located in the middle part of the current season's shoot growth on lower limbs (1.5 to $2.0 \mathrm{~m}$ height) from all the cardinal directions were collected every 2 or 3 weeks from May to October for $\mathrm{Zn}$ analysis. Complete nutrient analyses were conducted on leaflet samples collected in late July to determine the nutritional composition of the leaves. Immediately after sampling, leaves were washed using the following routine: washed in phosphate-free soap, rinsed in tap water, rinsed in distilled water, followed by three rinses in deionized water. Leaves were dried at $70{ }^{\circ} \mathrm{C}$ and ground with a mortar and pestle. During 2008, a rinse with hydrochloric acid $(1 \% \mathrm{v} / \mathrm{v})$ was added between the rinse with distilled water and rinse with deionized water. Complete analysis was conducted as follows. Nitrogen was determined by macroKjeldahl (Horowitz, 1980). For additional analysis, leaf tissue was ashed in a muffle furnace for $5 \mathrm{~h}$ at $500{ }^{\circ} \mathrm{C}$. Hydrochloric acid $(2.2 \mathrm{~N})$ was used to dissolve the ash. Phosphorus was determined colorimetrically (Olsen and Sommers, 1982). Potassium, calcium, magnesium, sulfur, iron, Zn, copper, manganese were assayed by atomic absorption spectroscopy (Motzz Laboratory, Inc., Tempe, AZ).

Leaflet size and chlorophyll index were determined on samples of 60 leaflets each summer. Chlorophyll index was obtained using a Konica Minolta SPAD 502 m (Konica Minolta Sensing America Inc., Ramsey, NJ) by optical density difference at two wavelengths (650 and $940 \mathrm{~nm}$ ). Chlorophyll readings were conducted on the middle pair of leaflets. Leaflets were scanned on a flatbed scanner and leaflet area obtained using Scion Image software (Scion Corp., Frederick, MD). Weights of dried leaves were also measured. During late July or early August, 20 middle pairs of leaflets were collected from the upper part of the canopy to compare leaf $\mathrm{Zn}$ concentration and leaf area with the ground level samples described previously.

\section{Results}

Zinc concentration in leaf tissue collected during the study is shown in Table 2. Significant differences were found as early as 1 month after injection of $\mathrm{Zn}$ fertilizers, although differences were not consistent over the duration of the study. Significant differences were found in $\approx 25 \%$ of the samples collected from 2005 through 2007, but not at all in 2008 . 
Foliar Zn levels were consistently lower than the critical level of $50 \mu \mathrm{g} \cdot \mathrm{g}^{-1}$ for pecans (Sparks, 1993, 1994) until 2008, when this level was reached in all treatments. Throughout the study, trees never exhibited visual $\mathrm{Zn}$ deficiency symptoms. During most of this study, the Zn-EDTA-treated trees had higher leaf $\mathrm{Zn}$ concentrations than the other two treatments; however, even in this treatment, leaflet $\mathrm{Zn}$ concentrations did not reach 50 $\mu \mathrm{g} \cdot \mathrm{g}^{-1}$ until the fourth year after treatment application. In 2005, leaf $\mathrm{Zn}$ concentrations were significantly higher in the leaves on the upper half of the trees as compared with the lower canopy leaves, although in 2007, there was no difference in leaf $\mathrm{Zn}$ concentration in the two parts of the trees. In 2008, differences in leaf $\mathrm{Zn}$ between lower and upper leaflets were not significant for the control treatment, but leaf $\mathrm{Zn}$ levels in the Zn-EDTA and zinc sulfate treatments were lower in the upper canopy compared with the lower part of the tree.

Zinc treatments did not affect growth of pecan trees (Table 3). Trunk cross-sectional area was unaffected and growth from 2006 to 2008 was unaffected by treatments. The increase in TCSA was slightly higher for the $\mathrm{Zn}$-EDTA treatment than the rest of the treatments; however, differences were not significant. Chlorophyll indices ranged from 47.5 to 48.0 in 2007 and from 44.7 to 45.4 in 2008. No significant differences were found among treatments.

In the 4 years after soil $\mathrm{Zn}$ application, no effect was found on nut yield or quality (Table 4). The 2005 season was a highyielding "on" year. This was followed by a low-yielding "off" year and then another high/ low yield cycle. Variations in yields in consecutive years were quite similar in all treatments. Cumulative yield among $\mathrm{Zn}$ treatments over the 3 years of the study also was not significantly different, but Zn-EDTA had the highest yield. Notably, the annual nut yields of the $\mathrm{Zn}$-EDTA-treated trees increased relative to that of the other treatments each yield cycle.

Nut quality was unaffected by treatments (Table 5). Kernel percentage was over 61.2 in all the years of evaluation. Nut weight ranged from 7.0 to $8.4 \mathrm{~g}$ per nut. The percentage of nuts exhibiting vivipary was between $2.6 \%$ and $11.0 \%$ and the percentage of stick tights ranged from $2.6 \%$ to $11.2 \%$. Neither disorder was affected by $\mathrm{Zn}$ treatments.

In 2 of 4 years, leaflet manganese (Mn) concentration was significantly lower in $\mathrm{Zn}$ EDTA-treated trees than in other treatments (Table 6). The decrease in Mn level in $\mathrm{Zn}$ EDTA trees was $14 \%$ in 2006 and $10 \%$ in 2007. The same relationship was noted in 2008, but the difference was not significant. Concentrations of other nutrients in leaflet tissues were unaffected by treatment.

\section{Discussion}

Leaflet Zn levels below $50 \mu \mathrm{g} \cdot \mathrm{g}^{-1}$ did not cause visual deficiency symptoms in this study. In the first season after soil $\mathrm{Zn}$ application (2005), late July leaflet Zn concen- trations ranged from 15 to 22 , in 2006 from 33 to 38 , in 2007 from 39 to 42 , and in 2008 from 44 to $58 \mu \mathrm{g} \cdot \mathrm{g}^{-1}$. Leaflet $\mathrm{Zn}$ concentration below the critical level of $50 \mu \mathrm{g} \cdot \mathrm{g}^{-1}$ (Sparks, 1993, 1994; Wood, 2007) during the first years of the study could be the result of rapid growth of the young 'Wichita' trees.

Leaflet $\mathrm{Zn}$ concentrations increased as the study progressed, even in the untreated control plots. The reasons for this are not clear. However, in 2007, manure applications were started as part of a switch from "conventional" to "organic" production. This may be related to the high $\mathrm{Zn}$ concentrations in 2008 ,

although it does not explain the increase from 2005 to 2006. In 2008, numerous fruiting bodies of the ectomycorrhizal fungi Pisolithus tinctorius and Scleroderma bovista were found in the orchard. Development of mycorrhizal fungi is known to enhance uptake of several nutrients, including $\mathrm{Zn}$. It is not known whether these fungi were a factor in data obtained in the current study.

Nut yield and quality did not appear to be related to leaflet $\mathrm{Zn}$, although lack of response of foliar $\mathrm{Zn}$ concentrations to soil $\mathrm{Zn}$ fertilizer treatments made this relationship difficult to assess. It is possible that all trees

Table 2. Effect of soil zinc $(\mathrm{Zn})$ fertilization on leaflet $\mathrm{Zn}$ concentration during the growing season in 'Wichita' pecan trees $\left(\mu \mathrm{g} \cdot \mathrm{g}^{-1}\right.$ dry weight).

\begin{tabular}{|c|c|c|c|c|c|c|c|c|}
\hline \multirow[b]{2}{*}{ Zn source } & \multicolumn{8}{|c|}{2005} \\
\hline & 18 May & 20 June & 11 July & 5 Aug. & 2 Sept. & $30 \mathrm{Sep}$ & & 5 Aug. top z \\
\hline$\overline{\text { Control }}$ & 36 & $15 \mathrm{~b}$ & $21 \mathrm{~b}$ & 20 & $18 \mathrm{~b}$ & 16 & & 28 \\
\hline Zinc sulfate & 35 & $21 \mathrm{ab}$ & $23 \mathrm{ab}$ & 25 & $18 \mathrm{~b}$ & 20 & & 27 \\
\hline Zn-EDTA & 36 & $23 \mathrm{a}$ & $29 \mathrm{a}$ & 29 & $29 \mathrm{a}$ & 27 & & 35 \\
\hline \multirow[t]{3}{*}{$\operatorname{Pr}>\mathrm{F}$} & NS & $*$ & * & NS & $* *$ & NS & & NS \\
\hline & \multicolumn{8}{|c|}{2006} \\
\hline & 9 May & 9 June & 26 June & 11 July & 27 July & 11 Aug. & 29 Aug. & 21 Sept. \\
\hline Control & 45 & 30 & 32 & 32 & 29 & 30 & 29 & $25 \mathrm{~b}$ \\
\hline Zinc sulfate & 62 & 35 & 35 & 33 & 33 & 33 & 35 & $32 \mathrm{ab}$ \\
\hline Zn-EDTA & 64 & 39 & 37 & 42 & 42 & 35 & 36 & $35 \mathrm{a}$ \\
\hline $\operatorname{Pr}>F$ & NS & NS & NS & NS & NS & NS & NS & $* *$ \\
\hline & & & & & 2007 & & & \\
\hline
\end{tabular}

\begin{tabular}{|c|c|c|c|c|c|c|c|c|c|c|}
\hline & 3 May & 22 May & 7 June & 21 June & 10 July & 26 July & 14 Aug. & 5 Sept. & 2 Oct. & $\begin{array}{c}5 \text { Sept. } \\
\text { top }\end{array}$ \\
\hline$\overline{\text { Control }}$ & 45 & 37 & 35 & 32 & 29 & 29 & $32 a b$ & $24 \mathrm{ab}$ & 24 & 29 \\
\hline Zinc sulfate & 50 & 39 & 38 & 33 & 31 & 35 & $29 \mathrm{~b}$ & $22 b$ & 28 & 30 \\
\hline Zn-EDTA & 50 & 42 & 38 & 37 & 32 & 42 & $41 \mathrm{a}$ & $29 a$ & 30 & 33 \\
\hline $\operatorname{Pr}>F$ & NS & NS & NS & NS & NS & NS & $*$ & $*$ & NS & NS \\
\hline & & & & & & 2008 & & & & \\
\hline
\end{tabular}

\begin{tabular}{|c|c|c|c|c|c|c|c|c|c|}
\hline & 30 May & 14 June & 2 July & 17 July & 30 July & 14 Aug. & 3 Sept. & 20 Sept. & $\begin{array}{l}14 \text { Aug. } \\
\text { top }\end{array}$ \\
\hline Control & 48 & 61 & 50 & 50 & 56 & 52 & 45 & 43 & 40 \\
\hline Zinc sulfate & 56 & 64 & 44 & 58 & 63 & 56 & 46 & 45 & 34 \\
\hline Zn-EDTA & 56 & 74 & 53 & 71 & 67 & 62 & 46 & 48 & 36 \\
\hline $\operatorname{Pr}>\mathrm{F}$ & NS & NS & NS & NS & NS & NS & NS & NS & NS \\
\hline $\begin{array}{l}\text { Most significant } \\
\text { difference }(0.05)\end{array}$ & - & - & - & - & - & - & - & - & - \\
\hline
\end{tabular}

${ }^{\mathrm{z}}$ Leaves from the upper half of the tree canopy.

NS, $*, * *=$ Nonsignificant or significant at $P \leq 0.05$ or 0.01 , respectively.

Table 3. Effect of soil zinc ( $\mathrm{Zn})$ fertilization on growth parameters of 'Wichita' pecan trees.

\begin{tabular}{|c|c|c|c|c|c|}
\hline \multicolumn{6}{|c|}{ Year } \\
\hline Zn source & 2005 & 2006 & 2007 & 2008 & \\
\hline \multicolumn{5}{|c|}{ Trunk cross-sectional area $\left(\mathrm{cm}^{2} /\right.$ tree $)$} & Growth 2006-2008 \\
\hline Control & - & 440 & 497 & 562 & 125 \\
\hline Zinc sulfate & - & 444 & 499 & 552 & 112 \\
\hline Zn-EDTA & - & 416 & 477 & 536 & 122 \\
\hline $\operatorname{Pr}>\mathrm{F}$ & & NS & NS & NS & NS \\
\hline \multicolumn{6}{|c|}{ Leaflet area top $\left(\mathrm{cm}^{2} /\right.$ leaflet $)$} \\
\hline Control & 19.4 & — & 24.3 & 23.5 & \\
\hline Zinc sulfate & 19.4 & — & 22.3 & 23.5 & \\
\hline Zn-EDTA & 19.7 & 一 & 24.1 & 24.5 & \\
\hline $\operatorname{Pr}>\mathrm{F}$ & NS & & NS & NS & \\
\hline \multicolumn{6}{|c|}{ Leaflet area ground $\left(\mathrm{cm}^{2} /\right.$ leaflet $)$} \\
\hline Control & 23.2 & 28.4 & 25.0 & 19.0 & \\
\hline Zinc sulfate & 27.8 & 24.3 & 24.5 & 20.4 & \\
\hline Zn-EDTA & 26.5 & 24.4 & 23.3 & 20.0 & \\
\hline $\operatorname{Pr}>\mathrm{F}$ & NS & NS & NS & NS & \\
\hline \multicolumn{6}{|c|}{ Chlorophyll index (SPAD) } \\
\hline Control & - & - & 47.8 & 45.6 & \\
\hline Zinc sulfate & - & - & 48.0 & 45.4 & \\
\hline Zn-EDTA & - & - & 47.5 & 44.7 & \\
\hline $\operatorname{Pr}>\mathrm{F}$ & & & NS & NS & \\
\hline
\end{tabular}

NS, $*, * *=$ Nonsignificant or significant at $P \leq 0.05$ or 0.01 , respectively. 
Table 4. Effect of soil zinc ( $\mathrm{Zn})$ application on yield and alternate bearing of 'Wichita' pecan trees.

\begin{tabular}{|c|c|c|c|c|c|}
\hline \multicolumn{6}{|c|}{ Year } \\
\hline Zn source & 2005 & 2006 & 2007 & 2008 & \\
\hline \multicolumn{5}{|c|}{ Yield of nut $\left(\mathrm{kg} \cdot \mathrm{ha}^{-1}\right)$} & Cumulative \\
\hline Control & 3,789 & 1,297 & 3,415 & 1,693 & 10,195 \\
\hline Zinc sulfate & 3,935 & 1,141 & 3,422 & 1,688 & 10,187 \\
\hline Zn-EDTA & 3,415 & 1,382 & 3,932 & 1,928 & 10,658 \\
\hline $\operatorname{Pr}>\mathrm{F}$ & NS & NS & NS & NS & NS \\
\hline \multicolumn{6}{|c|}{ Cumulative alternate bearing intensity (Cum. I) } \\
\hline Control & - & 0.49 & 0.46 & 0.43 & \\
\hline Zinc sulfate & - & 0.45 & 0.51 & 0.46 & \\
\hline Zn-EDTA & 一 & 0.52 & 0.44 & 0.44 & \\
\hline $\operatorname{Pr}>\mathrm{F}$ & & NS & NS & NS & \\
\hline \multicolumn{5}{|c|}{ Nut yield efficiency $\left(\mathrm{g} \cdot \mathrm{cm}^{-2}\right)$} & Cumulative \\
\hline Control & 73 & 25 & 57 & 42 & 151 \\
\hline Zinc sulfate & 75 & 22 & 57 & 45 & 154 \\
\hline Zn-EDTA & 69 & 28 & 69 & 41 & 166 \\
\hline $\operatorname{Pr}>\mathrm{F}$ & NS & NS & NS & NS & NS \\
\hline \multicolumn{5}{|c|}{ Yield of kernel $\left(\mathrm{kg} \cdot \mathrm{ha}^{-1}\right)$} & Cumulative \\
\hline Control & 2,079 & 692 & 2,127 & 1,071 & 5,902 \\
\hline Zinc sulfate & 2,077 & 612 & 2,160 & 1,061 & 5,916 \\
\hline Zn-EDTA & 2,411 & 719 & 2,498 & 1,221 & 6,270 \\
\hline $\mathrm{Pr}>\mathrm{F}$ & NS & NS & NS & NS & NS \\
\hline
\end{tabular}

Ns, ${ }^{*}, * *=$ Nonsignificant or significant at $P \leq 0.05$ or 0.01 , respectively.

contained adequate $\mathrm{Zn}$ for optimal production. Varying critical levels have been established for pecans and several researchers noticed no difference in pecan performance when $\mathrm{Zn}$ levels were above 36 to $35 \mu \mathrm{g} \cdot \mathrm{g}^{-1}$ (Sparks, 1976). Other reported critical levels are: $20 \mu \mathrm{g} \cdot \mathrm{g}^{-1}$ (Lane et al., 1965), $40 \mu \mathrm{g} \cdot \mathrm{g}^{-1}$ (Worley et al., 1972), and $60 \mu \mathrm{g} \cdot \mathrm{g}^{-1}$ (Storey et al., 1971). A sufficiency range of 50 to 100 $\mu \mathrm{g} \cdot \mathrm{g}^{-1}$ has been proposed (Sparks and Payne, 1982). The preferred leaf level of $\mathrm{Zn}$ for pecans in Louisiana is 50 to $150 \mu \mathrm{g} \cdot \mathrm{g}^{-1}$ (O'Barr et al., 1978). Seedlings of 'Curtis' growing in nutrient solution without $\mathrm{Zn}$ contained 24 to $37 \mu \mathrm{g} \cdot \mathrm{g}^{-1}$ of $\mathrm{Zn}$, at which levels seedlings showed mild Zn deficiency symptoms (Sparks, 1978). In Georgia, highyielding pecans (greater than $58 \mathrm{~kg}$ nuts per tree) had an average of $126 \mu \mathrm{g} \cdot \mathrm{g}^{-1} \mathrm{Zn}$ in leaves, and the $\mathrm{CV}$ was $60 \%$ (Beverly and
Worley, 1992). Optimum concentration in Mexico was determined to be $65 \mu \mathrm{g} \cdot \mathrm{g}^{-1}$ (Medina, 2004) and in the southwestern United States $174 \mu \mathrm{g} \cdot \mathrm{g}^{-1}$ (Pond et al., 2006). In our study, average annual yield 3 years after application was over $2800 \mathrm{~kg} \cdot \mathrm{ha}^{-1}$, which is considered very acceptable, nut quality was excellent, and kernel yield was over $61 \%$.

These data imply that a critical level of 50 $\mu \mathrm{g} \cdot \mathrm{g}^{-1}$ is probably too high. Pecans grown in hydroponic sand culture with nutrient solution omitting $\mathrm{Zn}$ exhibited interveinal necrosis in leaves with $7.2 \mu \mathrm{g} \cdot \mathrm{g}^{-1}$, mottling at 9.8 $\mu \mathrm{g} \cdot \mathrm{g}^{-1}$, and no symptoms in leaves with 11.2 $\mu \mathrm{g} \cdot \mathrm{g}^{-1}$ (Kim et al., 2002).

The size of the leaflets ( 23.5 to $24.5 \mathrm{~cm}^{2}$ / leaflet) was larger than those reported for 'Choctaw' pecan trees in shoots from the spring flush with $18.5 \mathrm{~cm}^{2} /$ leaflet (Andersen and Brodbeck, 1988).
Table 5. Effect of soil zinc ( $\mathrm{Zn}$ ) fertilization on nut quality of 'Wichita' pecan trees.

\begin{tabular}{|c|c|c|c|c|}
\hline \multirow[b]{2}{*}{ Zn source } & \multicolumn{4}{|c|}{ Year } \\
\hline & 2005 & 2006 & 2007 & 2008 \\
\hline \multicolumn{5}{|l|}{ Kernel (\%) } \\
\hline Control & 62.3 & 61.5 & 62.0 & 63.3 \\
\hline Zn sulfate & 62.5 & 62.3 & 63.2 & 62.8 \\
\hline Zn-EDTA & 62.4 & 61.2 & 63.6 & 63.4 \\
\hline $\operatorname{Pr}>\mathrm{F}$ & NS & NS & NS & NS \\
\hline \multicolumn{5}{|l|}{ Nut weight (g) } \\
\hline Control & 8.0 & 8.2 & 7.8 & 7.2 \\
\hline Zinc sulfate & 8.1 & 8.1 & 8.4 & 7.4 \\
\hline Zn-EDTA & 7.9 & 7.7 & 8.0 & 7.0 \\
\hline $\operatorname{Pr}>\mathrm{F}$ & NS & NS & NS & NS \\
\hline \multicolumn{5}{|l|}{ Vivipary (\%) } \\
\hline Control & 8.3 & 6.0 & 7.3 & 2.6 \\
\hline Zinc sulfate & 11.0 & 8.4 & 9.2 & 4.4 \\
\hline Zn-EDTA & 7.0 & 6.5 & 6.4 & 3.7 \\
\hline $\operatorname{Pr}>\mathrm{F}$ & NS & NS & NS & NS \\
\hline \multicolumn{5}{|l|}{ Stick tights $(\%)$} \\
\hline Control & 6.5 & 9.6 & 3.3 & 4.4 \\
\hline Zinc sulfate & 4.3 & 7.1 & 2.6 & 3.9 \\
\hline Zn-EDTA & 7.0 & 11.2 & 4.5 & 3.7 \\
\hline $\mathrm{Pr}>\mathrm{F}$ & NS & NS & NS & NS \\
\hline
\end{tabular}
or 0.01 , respectively.

There are few previously published chlorophyll index values for pecan leaves with which to compare our data. A previous study positively related leaf chlorophyll content to leaf $\mathrm{Zn}$ concentration (Hu and Sparks, 1991). Because the yield and quality of nuts from the studied trees were excellent in this study, the chlorophyll indices of these trees can be considered acceptable for 'Wichita' pecan trees in the irrigated southwestern United States. 'Pawnee' leaflets in Texas had similar values as those obtained for 'Wichita' in our study (Lombardini et al., 2005). In several crops as birch, wheat, and potato, soil plant analysis development (SPAD) indices of 50 to 52 represent chlorophyll concentrations of 4 to $5 \mathrm{mg}$ of total chlorophyll per gram (fresh weight) of leaf (Uddling et al., 2007). We calculated that $1 \mathrm{~g}$ of fresh leaflet tissue in our

Table 6. Effect of soil zinc ( $\mathrm{Zn}$ ) fertilization on leaf mineral composition of adult pecan 'Wichita' pecan trees (July leaf samples, dry matter).

\begin{tabular}{|c|c|c|c|c|c|c|c|c|c|c|c|}
\hline & Nitrogen & Phosphorus & Potassium & Calcium & Magnesium & Sulfur & Iron & Zinc & Copper & Manganese & Boron \\
\hline & \multicolumn{6}{|c|}{$\left(\mathrm{g} \cdot \mathrm{kg}^{-1}\right)$} & \multicolumn{5}{|c|}{$\left(\mathrm{mg} \cdot \mathrm{kg}^{-1}\right)$} \\
\hline Treatment & & & & & 2005 & & & & & & \\
\hline Control & 25.0 & 0.9 & 10.8 & 13.8 & 3.1 & 1.9 & 58.5 & 15 & 4.6 & 262 & 112 \\
\hline Zn sulfate & 25.0 & 1.0 & 11.8 & 14.8 & 3.2 & 2.0 & 75 & 22 & 5.2 & 290 & 125 \\
\hline Zn-EDTA & 24.0 & 0.9 & 11.0 & 13.8 & 3.1 & 2.0 & 66 & 20 & 4.7 & 265 & 112 \\
\hline $\operatorname{Pr}>\mathrm{F}$ & NS & NS & NS & NS & $\begin{array}{c}\text { NS } \\
2006\end{array}$ & NS & NS & NS & NS & NS & NS \\
\hline Control & 26.5 & 1.2 & 11.5 & 22.0 & 4.5 & 2.5 & 81 & 33 & 14.8 & $298 a^{z}$ & 109 \\
\hline Zn sulfate & 27.3 & 1.1 & 11.5 & 21.3 & 4.4 & 2.5 & 86 & 34 & 14.8 & $295 \mathrm{a}$ & 109 \\
\hline Zn-EDTA & 27.3 & 1.1 & 11.5 & 20.0 & 4.3 & 2.5 & 88 & 38 & 15.5 & $255 \mathrm{~b}$ & 99 \\
\hline $\operatorname{Pr}>\mathrm{F}$ & NS & NS & NS & NS & $\begin{array}{c}\mathrm{NS} \\
2007\end{array}$ & NS & NS & NS & NS & * & NS \\
\hline Control & 24.7 & 1.2 & 12.6 & 25.5 & 5.4 & 3.0 & 76 & 39 & 9.6 & $275 \mathrm{a}$ & 98 \\
\hline Zn sulfate & 24.4 & 1.2 & 12.9 & 26.2 & 5.3 & 2.8 & 71 & 32 & 9.0 & $281 \mathrm{a}$ & 100 \\
\hline Zn-EDTA & 24.3 & 1.2 & 12.9 & 24.8 & 5.6 & 3.0 & 76 & 42 & 9.8 & $246 \mathrm{~b}$ & 98 \\
\hline $\operatorname{Pr}>\mathrm{F}$ & NS & NS & NS & NS & $\begin{array}{c}\mathrm{NS} \\
2008\end{array}$ & NS & NS & NS & NS & * & NS \\
\hline Control & 22.0 & 1.1 & 13.5 & 24.3 & 4.9 & 2.0 & 86 & 44 & 8.7 & 267 & 98 \\
\hline Zn sulfate & 21.5 & 1.0 & 13.0 & 24.0 & 4.6 & 2.0 & 98 & 48 & 8.5 & 247 & 105 \\
\hline Zn-EDTA & 21.3 & 1.0 & 13.5 & 24.0 & 4.8 & 2.0 & 90 & 58 & 8.5 & 210 & 106 \\
\hline$\underline{\operatorname{Pr}>F}$ & NS & NS & NS & NS & NS & NS & NS & NS & NS & NS & NS \\
\hline
\end{tabular}

Numbers in a column followed by different letters are significantly different at $P<0.05$.

Ns, $*, * *=$ Nonsignificant or significant at $P \leq 0.05$ or 0.01 , respectively. 
study contained $\approx 4$ to $5 \mathrm{mg}$ of chlorophyll. $\mathrm{Hu}$ and Sparks (1991) found that fresh 'Mohawk' leaflets contained $3.2 \mathrm{mg}$ of chlorophyll/g of fresh leaves.

Alternate bearing intensity (I) measured as a variation in yield in consecutive years was very high, over 0.45 in 2 years of study, over 0.44 in 3 years, and more than 0.43 over 4 years. In Sonora, Mexico, I for 'Wichita' pecan trees has been reported to be 0.26 over seven seasons (Nunez, 2001) and in Georgia 0.51 in young trees and 0.67 in mature trees (Conner and Worley, 2000).

Yield efficiency was high in the "on" years and very low in the "off" years. It increased in the Zn-EDTA plots over the course of the study, and this treatment had the highest cumulative yield efficiency, but no differences could be attributed to treatments.

Zn-EDTA application decreased Mn leaflet levels. This could be the result of an antagonism between $\mathrm{Zn}$ and $\mathrm{Mn}$, which has previously been reported (Mengel and Kirkby, 1987). It has also been noted that low leaf $\mathrm{Zn}$ is accompanied by high leaf Mn concentrations (Kim et al., 2002). Additionally, increasing the $\mathrm{Mn}$ concentration in a nutrient medium from 0 to $14.78 \mathrm{~g} \cdot \mathrm{L}^{-1}$ decreased leaf Zn levels in 'Desirable' pecan seedling leaflets from 137 to $43.5 \mu \mathrm{g} \cdot \mathrm{g}^{-1}$ (O'Barr et al., 1987). Leaflet Mn increased from 187 to $4525 \mu \mathrm{g} \cdot \mathrm{g}^{-1}$.

In our study, leaflet $\mathrm{Zn}$ levels were not consistently affected by banding $\mathrm{Zn}$ in a calcareous soil. Similarly, banding a comparable rate of $\mathrm{Zn}$ (69 $\mathrm{kg} \mathrm{Zn/ha}$ as zinc sulfate) in an acidic soil ( $\mathrm{pH} 4.8$ to 5.2) did not increase leaflet $\mathrm{Zn}$ levels above $50 \mu \mathrm{g} \cdot \mathrm{g}^{-1}$ (Payne and Sparks, 1982a). In that study, leaflet $\mathrm{Zn}$ levels above this critical level were obtained by only applying $138 \mathrm{~kg} \mathrm{Zn/ha,} \mathrm{and}$ these concentrations were reached 6 years after $\mathrm{Zn}$ was banded. Banding $63 \mathrm{~kg} \mathrm{Zn} / \mathrm{ha}$ as $\mathrm{ZnSO}_{4}$ over a drip-emitter irrigation system did not raise leaf $\mathrm{Zn}$ levels above $50 \mu \mathrm{g} \cdot \mathrm{g}^{-1}$ until 4 years after application in young 'Desirable' trees (Wood, 2007).

Four years after the initiation of this study in a calcareous soil with a $\mathrm{pH}$ of 7.6 , all treatments, including the control treatment, had leaflet $\mathrm{Zn}$ levels above the critical level. Reasons for the increase in foliar $\mathrm{Zn}$ concentration over the course of the study could be related to the conversion of this orchard to organic production, which included a shift to mowing for weed control instead of the previously used soil cultivation. Extensive earthworm and mycorrhizae activity is now much more apparent than at the beginning of the study. Also, increased presence of feeder roots was noted in the shallow surface soil and in the leaf litter. These conditions can affect nutrition of plants (Sharpe and Marx, 1986).
Zn-EDTA occasionally increased Zn uptake by 'Wichita' pecan trees in alkaline, calcareous soil over the 4 years after a single band application. Yield, nut quality, and growth were unaffected by any of the experimental treatments. At this time, this $\mathrm{Zn}$ fertilization method cannot be recommended for established pecans in the southwestern United States. Additional research to evaluate application methods and $\mathrm{Zn}$ sources is needed to find appropriate methods for soil $\mathrm{Zn}$ application in southwestern pecan orchards.

\section{Literature Cited}

Agbenin, J.O. 2003. Zinc fractions and solubility in a tropical semiarid soil under long-term cultivation. Biol. Fertil. Soils 37:83-89.

Andersen, P.C. and B.V. Brodbeck. 1988. Net $\mathrm{CO}_{2}$ assimilation and plant water relations characteristics of pecan growth flushes. J. Amer. Soc. Hort. Sci. 113:444-450.

Beverly, R.B. and R.E. Worley. 1992. Preliminary DRIS diagnostic norms for pecan. HortScience 27:271.

Conner, P.J. and R.E. Worley. 2000. Alternate bearing intensity of pecan cultivars. HortScience 35:1067-1069.

Grauke, L.J., J.B. Storey, E.R. Emino, and D.W Reed. 1982. The influence of leaf surface, leaf age, and humidity on the foliar absorption of zinc from 2 zinc sources by pecan. HortScience 17:474.

Hendricks, D.M. 1985. Arizona soils. College of Agriculture University of Arizona, Tucson, AZ

Horowitz, W. 1980. Official methods of analysis of the Association of Analytical Chemist. Assn. Offic. Anal. Chem. Washington DC.

Hu, H. and D. Sparks. 1991. Zinc-deficiency inhibits chlorophyll synthesis and gas-exchange in Stuart pecan. HortScience 26:267-268.

Karaca, A., O. Turgay, and S. Arcak. 2000. Effect of EDTA on the extractability of zinc, cadmium, and nickel in soils. Proceedings of International Symposium on Desertification, p. 422-428, 13-17 June 2000, Konya, Turkey.

Kim, T., H.A. Mills, and H.Y. Wetzstein. 2002. Studies on the effect of zinc supply on growth and nutrient uptake in pecan. J. Plant Nutr. 25:1987-2000.

Lane, R., H.F. Perkins, and J.F.E. Johnstone. 1965. Studies on the relationship of calcium, zinc, and $\mathrm{pH}$ in pecan production. Proc. S.E. Pecan Growers Assn. 58:21-24.

Lindsay, W.L. 1979. Chemical equilibria in soils. John Wiley \& Sons, New York, NY.

Lombardini, L., M.K. Harris, and D.M. Glenn. 2005. Effects of particle film application on leaf gas exchange, water relations, nut yield, and insect populations in mature pecan trees. HortScience 40:1376-1380.

Medina, C. 2004. Normas DRIS preliminares para nogal pecanero. Terra 22:445-450.

Mengel, K. and E.A. Kirkby. 1987. Principles of plant nutrition. Intl. Potash Inst. Bern, Switzerland.

Nunez, H. 2001. Desarrollo del nogal pecanero, p. 23-38. In: Duron, J. and H. Nunez (eds.). El nogal pecanero en Sonora. INIFAP, Hermosillo, Sonora.
O’Barr, R.D., J.M. McBride, and K. Hanson. 1978. Pecan leaf sampling reveals shortages of fertilizer nutrients. Louisiana Agr. 21:6-7.

O’Barr, R.D., S. Rachal, K. Koonce, and J. Kowalzuk. 1987. Influence of manganese applications on nine elements in pecan leaves, trunk and roots. Louisiana Agricultural Expt. Sta. Circ. Circ. 102-112.

Olsen, S.R. and L.E. Sommers. 1982. Phosphorus, 403-430. In: Page, A.L. and R.H. Miller (eds.). Methods of soil analysis. Part 2. Chemical and microbiological. 2nd ed. Ameri. Soc. Agron.Soil Sci. Soc. Amer., Madison, WI.

Payne, J.A. and D. Sparks. 1982a. Effect of broadcast and band application on zinc uptake by pecan trees. Pecan South. 9:25-27.

Payne, J.A. and D. Sparks. 1982b. Zinc levels in pecan leaflets from broadcast and band applications over a 6-year period. HortScience 17:235-236.

Pearce, S.C. and S. Dobersek-Urbanc. 1967. The measurement of irregularity in growth and cropping. J. Hort. Sci. 42:295-305.

Pond, A., J. Walworth, W.M. Kilby, R. Gibson, R. Call, and H. Nunez. 2006. Leaf nutrient levels for pecans. HortScience 41:1339-1341.

Sharpe, R.R. and D.H. Marx. 1986. Influence of soil $\mathrm{pH}$ and Pisolithus tinctorius ectomycorrhizae on growth and nutrient-uptake of pecan seedlings. HortScience 21:1388-1390.

Sparks, D. 1976. Zinc nutrition and the pecan. A review. Pecan South. 3:304-334.

Sparks, D. 1978. Nutrient concentrations of pecan leaves associated with deficiency symptoms and normal growth. HortScience 13:256-257.

Sparks, D. 1993. Threshold leaf levels of zinc that influence nut yield and vegetative growth in pecan. HortScience 28:1100-1102.

Sparks, D. 1994. Leaf zinc for maximum yield, growth in pecan. Pecan South. 27:19-24.

Sparks, D. and J.A. Payne. 1982. Zinc concentration in pecan leaflets associated with zinc deficiency symptoms. HortScience 17:670-671.

Storey, J.B., G. Wadsworth, M. Smith, and D. Westfall. 1971. Pecan zinc nutrition. Proc. S.E. Pecan Growers Assn. 64:87-91.

Uddling, J., J. Gelang-Alfredson, and K. Piikki. 2007. Evaluating the relationship between chlorophyll concentration and SPAD-502 chlorophyll meter readings. Photosynth. Res. 91:37-46.

Udo, E.J., H.L. Bohn, and T.C. Tucker. 1970. Zinc adsorption by calcareous soils. Soil Science Society of American Proc. 34:405-407.

Wadsworth, G. 1970. Absorption and translocation of zinc in pecan trees [Carya illinoensis (Wang.) K. Koch]. TAMU, College Station, TX. MSc thesis.

Wood, B.W. 2007. Correction of zinc deficiency in pecan by soil banding. HortScience 42:15541558.

Wood, B.W. and J.A. Payne. 1997. Comparison of $\mathrm{ZnO}$ and $\mathrm{ZnSO}_{4}$ for correcting severe foliar zinc deficiency in pecan. HortScience 32:5356.

Worley, R.E., R.L. Carter, and S.A. Harmon. 1972. Effect of zinc sources and methods of application on yield and leaf mineral concentration of pecan, Carya-Illinoensis. Koch. J. Amer. Soc. Hort. Sci. 97:364. 